\title{
THE EFFECT OF IRON INJECTION AT DIFFERENT AGES ON BABY PIG HAEMOGLOBIN
}

\author{
L. Hoffrén, V. Hoffrén and S. HaARAnEN \\ Clinical Veterinary Laboratory, Siilinjärvi
}

Received April 7, 1964

Numerous investigations have shown that baby pig haemoglobin decreases successively after birth $(1,7)$. This phenomenon is due to lack of iron because in the sow's milk the piglets receive only about $1 \mathrm{mg}$ of iron daily (4). The intestinal absorption of iron is poor, approximately $10-30$ per cent of the ingested amount depending on the amount of iron (5) and for every kilogram of bodyweight the piglet must have $25 \mathrm{mg}$ of iron to maintain a normal haemoglobin level in the growing body (2). The daily iron need is thus about $7 \mathrm{mg}$ (9). An additional iron supply is therefore necessary. Iron treatment per os is relatively laborious and is considered to be unreliable because it cannot fully prevent a decrease of the blood haemoglobin values $(1,5,8)$. By parenteral iron administration anaemia can be prevented. In practice $200 \mathrm{mg}$ iron intramuscularly usually covers the iron need for an 8 kilogram bodyweight increase. After this stage of growth the pigs usually receive their iron from food.

At our laboratory it was observed that the pigs receiving their iron injection soon after birth had better blood haemoglobin values for the first weeks of life than those receiving their iron later. To prove this observation the following investigation was made.

\section{Material and methods}

This work was made in 1961 at a swineherd which is free from contagious diseases As feeding does not to any remarkable extent affect the iron content of the sow's milk, the feeding of sows is excluded (8) from this study.

28 newborn pigs of primiparous sows were chosen as test animals. The pigs in the different litters were divided at random into groups of two, each pair being given an iron injection at $2,4,6,8,10,12$ and 14 days of age. The piglet pairs treated at the same age in different litters were then considered as a group. Altogether 7 test groups were thus obtained each comprising 4 pigs. The pigs were injected with 200 
mg of iron intramuscularly as colloidal ferric oxide in dextrin. ${ }^{(\mathrm{R})}$ Blood samples were obtained by ear vein puncture. The pigs were weighed at the same time as the blood samples were drawn. The animals were controlled in this way in every group on the 2'nd and the 42'nd day after birth and on the 2'nd, 4'th, 8'th and 14'th day after the injection. Blood haemoglobin determinations were made by the Ljungberg sodium carbonate method (6). Fisher's variance ratio $\left(\mathrm{v}^{2}\right)$, Student's t test, variance analysis and covariance analysis were used as statistical methods by testing the results if possible.

(R) Trade mark Pigdex 100 by American Cyanamid Co.

Table 1. The mean weight gain in test groups during 14 days after iron injection.

\begin{tabular}{cccc}
\hline $\begin{array}{c}\text { Day of injection } \\
\text { after birth }\end{array}$ & $\begin{array}{c}\text { Weight at } \\
\text { injection time, } \\
\mathrm{kg}\end{array}$ & $\begin{array}{c}\text { Weight 14 days } \\
\text { after injection, } \\
\mathrm{kg}\end{array}$ & $\begin{array}{c}\text { Weight gain, } \\
\mathrm{kg}\end{array}$ \\
\hline & & & 2.2 \\
4 & 2.0 & 4.2 & 3.2 \\
6 & 2.7 & 5.9 & 2.7 \\
8 & 2.9 & 5.6 & 2.2 \\
10 & 3.6 & 5.8 & 2.2 \\
12 & 3.3 & 5.5 & 2.7 \\
14 & 4.2 & 6.9 & 1.8 \\
\hline
\end{tabular}

Variance analysis of the mean weight increases in test groups after injection during 14 days' observation.

\begin{tabular}{cccccc}
\hline & $\begin{array}{l}\text { Sum of } \\
\text { squares }\end{array}$ & $\begin{array}{l}\text { Degree of } \\
\text { freedom }\end{array}$ & Variance & $\mathrm{v}^{2}$ & $\mathrm{P}$ \\
\hline $\mathrm{QB}_{\mathrm{B}}$ & 5.0 & 6 & 0.83 & 1.8 & - \\
$\mathrm{Q}_{0}$ & 9.3 & 20 & 0.46 & &
\end{tabular}

Table 2. The mean haemoglobin alteration before and after iron injection.

\begin{tabular}{ccc}
\hline $\begin{array}{c}\text { Days after } \\
\text { birth }\end{array}$ & $\begin{array}{c}\text { From birth } \\
\text { to injection }\end{array}$ & $\begin{array}{c}\text { From injection } \\
\text { to } \begin{array}{c}\text { 14 days after } \\
\text { injection }\end{array}\end{array}$ \\
\hline & & +3.28 \\
4 & \pm 0 & +2.44 \\
6 & +0.84 & +3.20 \\
8 & -2.08 & +4.71 \\
10 & -2.95 & +3.52 \\
12 & -1.72 & +3.56 \\
14 & -2.16 & +3.26 \\
\hline
\end{tabular}


Variance analysis of the mean haemoglobin increases after injection during 14 days' observation

\begin{tabular}{cccccc}
\hline & $\begin{array}{c}\text { Sum of } \\
\text { squares }\end{array}$ & $\begin{array}{c}\text { Degree of } \\
\text { freedom }\end{array}$ & Variance & $\mathrm{v}^{2}$ & $\mathrm{P}$ \\
\hline & & & & & \\
$\mathrm{Q}_{\mathrm{B}}$ & 16.04 & 6 & 2.67 & 0.56 & - \\
$\mathrm{Q}_{0}$ & 94.28 & 20 & 4.71 & & \\
\hline $\mathrm{Q}$ & 110.32 & 26 & &
\end{tabular}

\section{Results}

Table 1 shows that there were no statistical differences in weight gain after the iron injection between the 7 injection groups during 14 days of observation.

In Table 2 are presented the decreasing haemoglobin values in pigs after birth when no iron was supplied. In the groups which received their iron on the 6 'th day or later the blood haemoglobin level sank from a value of $7-11 \mathrm{~g} \%$ to $5-8 \mathrm{~g} \%$. This indicates that anaemia occurs rapidly after birth if no iron is supplied.

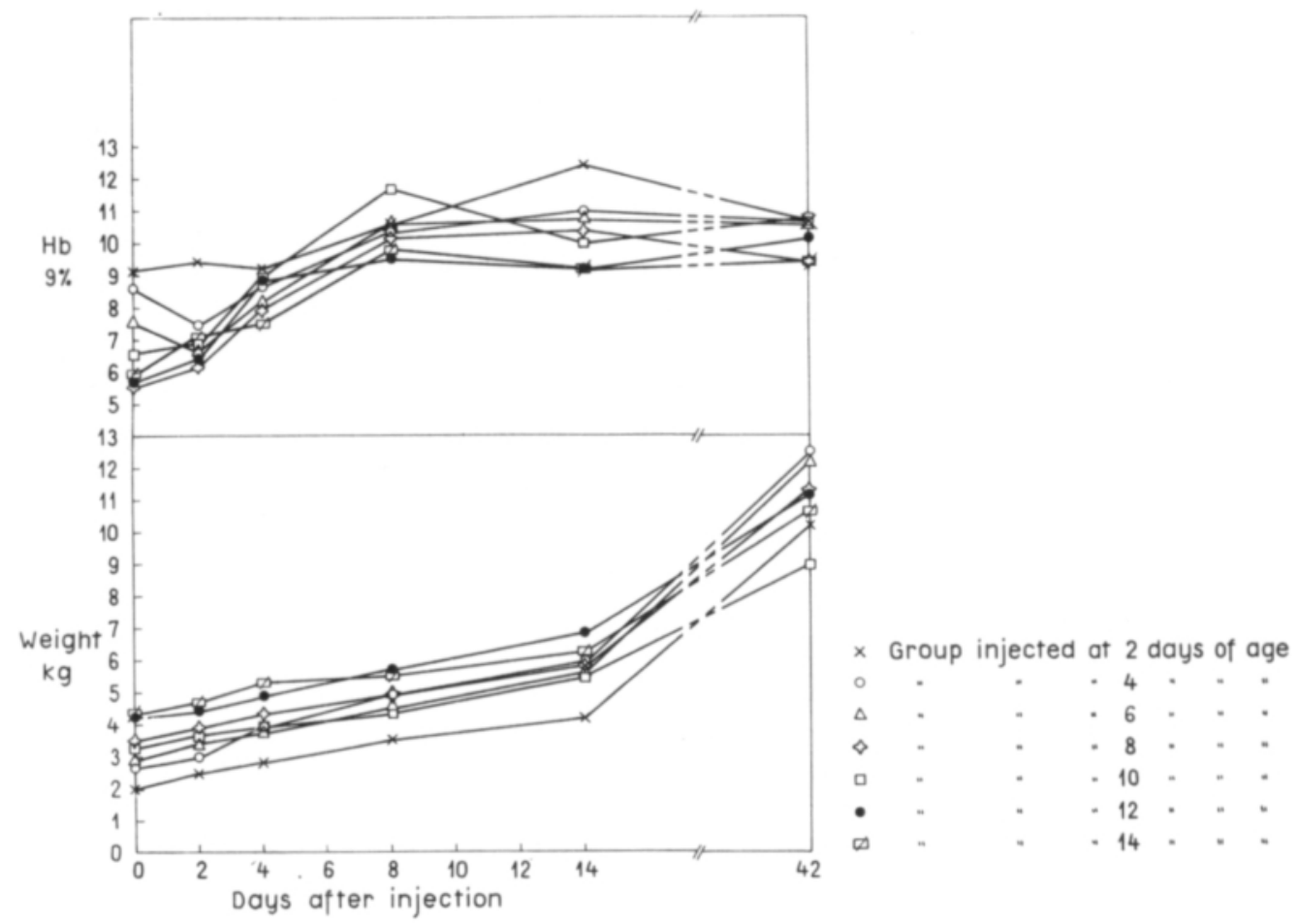

Figure 1. Effect of iron injection at different ages on baby pig haemoglobin and body weight during 42 days of observation after the iron injection. The group mean values, injected at different ages, are presented. 
After the iron injection the haemoglobin increased in all test groups. The mean haemoglobin increases in different groups did not differ significantly from each other.

Figure 1. shows the weight increases and the effects of iron injections on different days after birth. Haemoglobin in pigs injected at the age of two days remained at the highest level of the whole material for 14 days after the injection but decreased thereafter. On the 42 'nd day after the injection the haemoglobin values were nearly the same in all groups but the group mean weights of pigs injected at the age of 4-8 days were the highest.

In the group that received their iron at the age of 10 days there occurred a moderate dehydration in two resulting in an abnormal haemoglobin increase on the 8 'th day after the injection. In general when the haemoglobin values reached the level of 9-11 g per cent they remained at this level still on the 42'nd day after the injection. At that time the pigs were fed solely on a pig starter containing $30 \mathrm{ppm}$ of iron as a sulphate. The starter feeding was begun already at 3 weeks and it was given ad libitum. The weaning was performed at 6 weeks.

The correlation between the body weight and the blood haemoglobin was negative before injection $(r=-0,59)$, after the injection during the 14 days' observation period it was positive but not linear.

\section{Discussion}

No other cases as of illnesses occurred during the test period except the dehydration in the two pigs already mentioned. After the test some of the animals suffered from diarrhoea and one piglet died and was excluded from calculations. At birth the pigs were slightly anaemic, the mean haemoglobin value varied between $7,76-9,24 \mathrm{~g} \%$. After birth the haemoglobin values decreased very rapidly. This may be due to very intensive growth during the first week of life, which seems therefore to be the most critical period.

The anaemic condition does not seem to retard growth during the first week of life, nor does iron seem to accelerate it. On the contrary, some piglets receiving their iron at the age of $2-4$ days weighed less at the age of 2 weeks than the anaemic pigs injected at the age of 12-14 days. This may be due to some harmful effect in iron. Microangiopathia (MAP), which is considered to be an E vitamin and Se deficiency disease, was quite a common disease in the herd where this investigation was made. Iron as an oxidant can even precipitate this disease. Unfortunately serum transaminases could not be determined. In any case, no manifest symptoms of MAP were to be seen.

The anaemic condition in growing pigs can be calculated when no additional iron is supplied. If a pig weighs 2 kilograms and has a blood haemoglobin level of $9 \mathrm{~g} \%$ and total haemoglobin, say $12.6 \mathrm{~g}(2)$, the pig will weigh 3 kilograms after a week but still have the same amount of haemoglobin (or body iron). The haemoglobin will be "diluted" to $2 / 3$ and the $\mathrm{Hb}$ level will be $2 / 3 \times 9 \mathrm{~g} \%=6 \mathrm{~g} \%$ which is in agreement with practical findings. Because the observed haemoglobin dec- 
rease is about $2 \mathrm{~g} \%$ in a week and not $3 \mathrm{~g} \%$, the piglets must have received some iron in the sows milk. 5-7 mg of absorbed iron is sufficient for an haemoglobin level increase of $1 \mathrm{~g} \%(2)$. The feeding troughs of the sows were so placed that the piglets did not have access to the sows' food during the two firstweeks of life. As there were members of each injection group in every litter the feeding and living conditions were the same for all pigs injected at different ages.

\section{$S u m m$ ar $y$}

Baby pigs were given an iron injection $-200 \mathrm{mg}$ iron as iron dextrin intramuscularly at $2,4,6,8,10,12$ and 14 days of age. The pigs were weighed and their blood haemoglobin was determined at 2 and 42 days of age, in addition each group was treated in this way on the 2 'nd, 4 'th, 8 'th and $14^{\prime}$ 'th day after the injection. The haemoglobin values decreased with about $2 \mathrm{~g} \%$ in a week when no iron was supplied. After the injection the haemoglobin increased with $2.44-4.71 \mathrm{~g} \%$ in two weeks. The increases between different groups did not differ significantly from each other. Neither anaemia nor the iron injections had any significant influence on growth. In this study the blood haemoglobin remained at he highest level in pigs injected at the age of two days in the whole material during 42 days after birth but their growth was the smallest during that time. It can be concluded that a haemoglobin decrease can be prevented by iron injections but that iron can have a retarding effect on growth if injected at the age of two days, especially in herds where $\mathrm{E}$ vitamin and Se deficiency diseases are common.

R E F E R E N E S

(1) HaAranen, S. 1960. Some blood components of growing pigs. Nord veter. med. 12: $239-244$.

(2) - 1961. Anemian ehkäisystä porsailla. Sika 161: 11-15.

(3) Kernkamp, H. C. H., Clawson, A. J. \& Ferneyhough, R. H. 1962. Preventing iron deficiency anemia in baby pigs. J. An. Sci. 21: 527-532.

(4) LANneK, N. 1959. Förebyggande av smågrisanemi genom injektion av järndextranlösning. Medlemsbl. Sveriges veter. förb. 19: 1-4.

(5) Linkenheimer, W. H. 1960. Iron- its metabolism and application in baby pig anemia. Cyanamid Internat. Veter. Bull. 2: 23-32.

(6) Ljungberg. Colorimetric Application.

(7) Miller, E. R., Ullrey, D. E., Ackerman, I., Schmidt, D. A., Luecke, R. V. \& Hoefer, V. A. 1961. Swine hematology from birth to maturity. II. Erythrocyte population, size and hemoglobin concentration. J. An. Sci. 20: 890-897.

(8) Pond, W. G., Lowrey, R. S., Maner, J. H. \& Loosli, J. K. 1961. Parenteral iron administration to sows during gestation or lactation. J. An. Sci. 20: 747-750.

(9) Venn, J. A. J., Mc Cance, R. A. \& Widdowson, E. M. 1947. J. Comp. Path. and Therap. $57: 314$. (Cit. by 4.) 
L. Hoffrén, V. Hoffrén ja S. HaAranen

Klininen eläinlääkintälaboratorio, Siilinjärvi

Pikkuporsaille ruiskutettiin $200 \mathrm{mg}$ rautaa lihakseen rautadekstriinivalmisteena $2,4,6,8,10,12$ ja 14 vrk iässä. Porsaat punnittiin ja veren hemoglobiinipitoisuus tutkittiin 2 ja 42 vrk iässä sekä jokaisella ryhmällä vielä $2,4,8$ ja 14 vrk ruiskuttamisen jälkeen. Ennen rautaruisketta veren $\mathrm{Hb}$ aleni keskimäärin $2 \mathrm{~g}$ \% viikon sisällä. Rautaruiskeen jälkeen se kohosi kaikilla porsailla $2.44-4.71 \mathrm{~g} \%$ kahdessa viikossa. Hb-lisäysten ero eri iässä ruiskutetuilla porsailla ei ollut tilastollisesti merkitsevä. Anemia ei näyttänyt vaikuttavan hidastavasti kasvuun. Rautaruiske ei myöskään kiihoittanut kasvua, vaan näytti päinvastoin hidastavan sitä, jos ruiskutus tapahtui 2 vrk iässä. Kahden vuorokauden ikäisinä lisäraudan saaneilla porsailla veren $\mathrm{Hb}$ oli korkein 42 vrk ajan. Rautaruiskeella voidaan näin ollen tavallinen ensimmäisten elinviikkojen aikana ilmestyvä anemia torjua, mutta aikaisin suoritettu rautaruiske voi hidastaa kasvua, jos sikalassa esiintyy E-vitamiinin ja seleenin puutosoireita.

\title{
MAATALOUSTIETEELLINEN AIKAKAUSKIRJA TOIMITUSKUNTA
}

Erkki Kivinen, Jaakko Mukula, Antti Mäki, Onni Pohjakallio, Alpo Reinikainen

\author{
E. A. Jamalainen
}

Päätoimittaja

Tikkurila. Puh. 831419 ja 831318

MAATALOUSTIETEELLISTÁ AIKAKAUSKIRJAA

ilmestyy 4 vihkoa vuodessa

Käsikirjoitukset lähetetään päätoimittajalle (os. Tikkurila) tai jollekin toimitusvaliokunnan jäsenelle

\section{SUOMEN MAATALOUSTIETEELLINEN SEURA}

Puheenjohtaja:

Professori K. U. Pihkala

Palokunnant. 15, Rekola

Varapuheenjohtaja:

Tohtori Martti Sipilä

Kaarela, Helsinki
Sihteeri:

Professori V. Vainikainen

Laivurink. 35 B, Helsinki

Rahastonhoitaja:

Professori Orvo Ring

Tikkurila

\section{Kirjastonhoitaja:}

Maisteri Majlis Tulander, Hallituskatu 3, Helsinki 